\title{
ASCORBIC ACID IN BLACK CURRANT FRUITS
}

\author{
N. OSOKINA, Doctor of Agricultural Sciences \\ K. KOSTETSKA, PhD of Agricultural Sciences \\ H. GERASYMCHUK, PhD of Agricultural Sciences \\ Uman National University of Horticulture
}

Наведено результати 15-річних досліджень з вивчення вмісту аскорбінової кислоти у плодах чорної смородини. Під час вегетаиії чорної смородини було підраховано: суму ефективних температур вище $5^{\circ} \mathrm{C}$; суму ефективних температур вище $10{ }^{\circ}$; ; величину активних температур; кількість опадів; гідротермічний коефіиієнт (ГТК). Встановлено, щчо тривалість сезону вирощування чорної смородини в умовах Правобережного Лісостепу України становить $96 \pm 3-4$ дні. При чому сума ефективних температур вище $5^{\circ} \mathrm{C}$ складала 750-950 $10^{\circ} \mathrm{C}-300-600^{\circ}$, сума активних температур - 1050-1300 ${ }^{\circ}$ і опадів - 120 300 мм, ГTК - 0,7-3,0.

Ключові слова: чорна смородина, сорт, якість, хімічний склад, аскорбінова кислота.

State of the problem. Ascorbic acid plays an important function in the body. Comprehensive and extensive study of the most complex details in substances metabolism has shown that ascorbic acid has one of the responsible roles in the process of the whole cycle of fetal development of plants from emergence to extinction - the role of the direct participant in the process of respiration, photosynthesis, regulation of the activity of enzymes and coenzymes, general exchange and transport substances, protecting cells against oxidative stress induced by abiotic factors.

The biological role of ascorbic acid in the life of the human body is diverse: it participates in oxidation reducing processes, affects the protein, carbohydrate, mineral, cholesterol metabolism, is a participant in the formation of DNA of the cell nucleus, promotes the regeneration of the intercellular substance of connective tissues and the synthesis of collagen in the walls of blood vessels, reduces their permeability and increases elasticity, prevents atherosclerosis, provides resistance to stress, immunity and haematological status, promotes assimilation vitamins, and iron in the body, increases its resistance to infections, prevents premature aging, eliminates the effect of allergens and carcinogens $[1,2]$.

Analysis of recent studies and publications. Black currant (Ribes nigrum L.) is a source of ascorbic acid. Its content in fruits varies considerably $-44-218 \mathrm{mg} / 100 \mathrm{~g}$ [3], 50-350 mg/100 g [4], according to other data - 100-200 mg/100 g [5], 100-300 $\mathrm{mg} / 100 \mathrm{~g}[6-8]$. 
The ascorbic acid level in black currant fruits is influenced by numerous factors: peculiarities of the variety, area of cultivation, conditions of cultivation, age of the bush, branches, their location, size and part of the fetus, degree of its ripeness, and others [9-12]. Accumulation of ascorbic acid in currant fruits depends not only on the intensity of synthesis, but also on the activity of enzymes. A characteristic feature of black currant is the decrease in the ascorbic acid content until the end of the fruit ripeness in 1.3-2.3 and its higher level under less favourable weather conditions during the vegetation period [13]. The problem is the establishment of the laws of ascorbic acid accumulation in black currant fruits, depending on the internal and external factors.

The aim of the research is to analyze ascorbic acid content in black currant (Ribes nigrum L.) fruit during many years of research.

Materials and methods. Research tasks were meant to establish:

- black currant growth duration and agroclimatic indicators during this period;

- ascorbic acid content in black currant fruits depending on the variety and the year of the harvest.

The study of agroclimatic indices influence on the beginning, the end of the vegetation, the duration of the vegetation period and the ascorbic acid content in black currant fruit of Holiaf, Pilot O. Mamkin, Mynai Shmyrov, Biloruska solodka, and Novyna Prykarpattia were conducted during 15 years. According to observations recorded: the beginning of the growing season (at an air temperature above $5{ }^{\circ} \mathrm{C}$ ), rainfall falling before the harvest, the beginning and the end of mass harvesting.

According to Uman meteorological station, during the growing season of black currant it was counted [14]: the sum of effective temperatures above $5^{\circ} \mathrm{C}$; the sum of effective temperatures above $10{ }^{\circ} \mathrm{C}$; amounts of the active temperatures; amount of the rainfall; hydrothermal coefficient (HTC). The ascorbic acid content in black currant fruits was determined by the iodometric method (according to B. P. Pleshkov, 1976) [15]. The study of black currants was carried out in accordance with SSU 8319:2015. Repetition of chemical analyzes is threefold. Weight of the sample for analysis is $2 \mathrm{~kg}$ [16].

Research results. The ascorbic acid content in black currant fruits is given in Table 1.

Table 1. Ascorbic acid content in black currant fruits of different varieties

\begin{tabular}{|l|c|c|c|c|}
\hline Variety & $\begin{array}{c}\text { Research } \\
\text { years }\end{array}$ & $\begin{array}{c}\text { Change boundaries } \\
\text { over years, mg/100 g }\end{array}$ & $\begin{array}{c}\text { Average, } \\
\mathrm{mg} / 100 \mathrm{~g}\end{array}$ & $\begin{array}{c}\text { Variation } \\
\text { coefficient, \% }\end{array}$ \\
\hline Holiaf & 4 & $134.6-145.2$ & 142.6 & 4.4 \\
\hline Pilot O. Mamkin & 2 & $176.0-184.8$ & 180.4 & 3.5 \\
\hline Mynai Shmyrov & 15 & $101.2-202.4$ & 158.7 & 22.0 \\
\hline Novyna Prykarpattia & 15 & $118.8-229.3$ & 181.6 & 20.3 \\
\hline Biloruska solodka & 9 & $167.2-308.0$ & 241.8 & 16.9 \\
\hline Average & - & $101.2-308.0$ & 181.0 & - \\
\hline \multicolumn{2}{|c|}{$L S D_{05}$} & \multicolumn{3}{|c|}{} \\
\hline
\end{tabular}


Its fluctuation in fruits is quite high: from $101 \mathrm{mg} / 100 \mathrm{~g}$ (Mynai Shmyrov variety) to $308 \mathrm{mg} / 100 \mathrm{~g}$ (Biloruska solodka variety), that is, the difference is more than 3 times.

The variation coefficient in the fruits of these varieties shows the average and significant variation of the indicator. Moreover, with an increase in the duration of research, the coefficient increases, which indicates the influence of weather conditions on the synthesis of ascorbic acid.

According to Figure 1, the ascorbic acid content of in fruits has clearly distinguished varietal features. The variety impact strength on the ascorbic acid accumulation is $52 \%$, weather conditions impact on the vegetation period is $37 \%$.

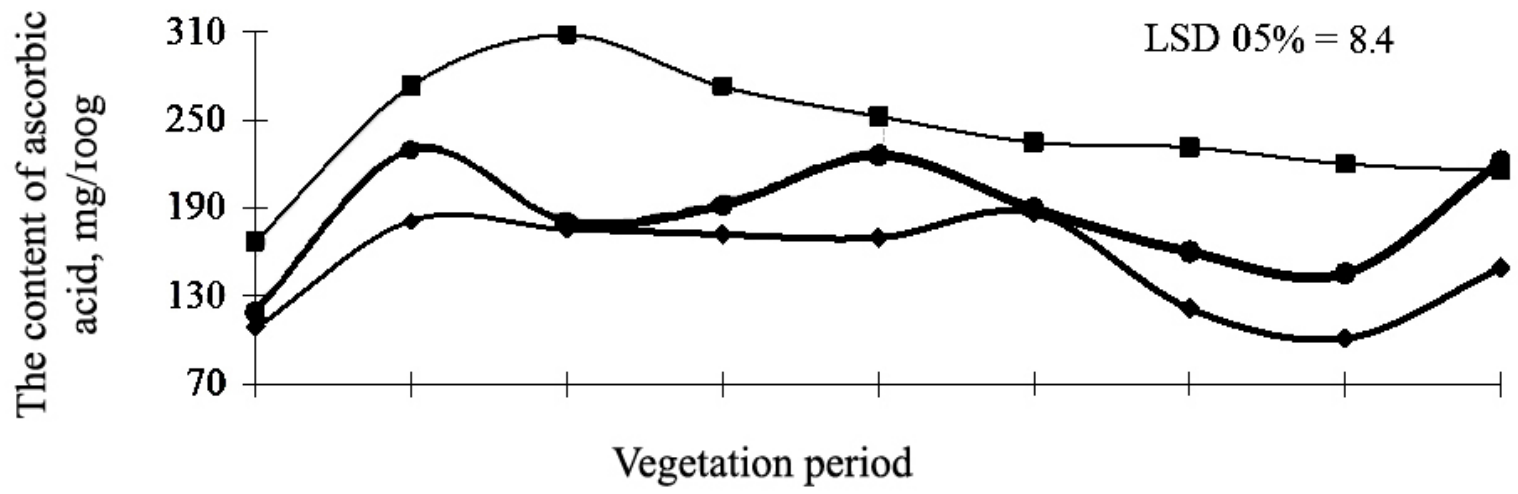

Fig. 1. The content of ascorbic acid in blackcurrant fruits of different varietes: $\rightarrow$ Munai Shmyrov; $\rightarrow$ Novyna Prykarpattia; $\rightarrow$ Biloruska solodka.

The highest content of ascorbic acid in the fruits of the Biloruska solodka variety is, on average, $241.8 \mathrm{mg} / 100 \mathrm{~g}$, which is 1.3 times more than in the fruits of the Poppy Pearl River variety and 1.6 times more than in the fruits of the Mynai Shmyrov variety. The ascorbic acid content in fruits of the Biloruska solodka variety is not only high, but also mostly stable within the average. In some years, its level rises to $272-308 \mathrm{mg} / 100 \mathrm{~g}$, and only in one - it was very low - $167 \mathrm{mg} / 100 \mathrm{~g}$.

The high content of ascorbic acid in fruits of the Novyna Prykarpattia variety is, on average, $184.9 \mathrm{mg} / 100 \mathrm{~g}$. However, stability in its synthesis was not observed. In some years its amount was $145.2-160.2 \mathrm{mg} / 100 \mathrm{~g}$ and $180.4-192.4 \mathrm{mg} / 100 \mathrm{~g}$, rising to $211.0-229.3 \mathrm{mg} / 100 \mathrm{~g}$ and could be seen at $118.8 \mathrm{mg} / 100 \mathrm{~g}$.

Fruits of Mynai Shmyrov variety were of a relatively low content of ascorbic acid, on average $151.9 \mathrm{mg} / 100 \mathrm{~g}$. It is to some extent a varied feature, but there are some significant fluctuations over the years. After all, the fruits could accumulate it $172.0-182.1 \mathrm{mg} / 100 \mathrm{~g}$ and $101.2-109.1 \mathrm{mg} / 100 \mathrm{~g}$. In order to assess the influence of weather conditions on the ascorbic acid synthesis, the thermal resources of the growing season and the moisture indices have been used.

According to the long-term studies (table 2), we have established that in the conditions of the Right-Bank Forest-Steppe Ukraine the beginning of the vegetation of black currant falls on the period from the 2nd decade of March to the first decade of April. 
Table 2. Agroclimatic indices during the black currant vegetation period (15 years) in the conditions of the Right Bank Forest-Steppe of Ukraine

\begin{tabular}{|c|c|c|c|c|c|c|c|c|}
\hline $\begin{array}{l}\text { Vegetation } \\
\text { period } \\
\text { duration, } \\
\text { days }\end{array}$ & $\begin{array}{c}\sum_{\text {effectiv }} \\
\text { e t } \\
>5^{\circ} \mathrm{C}\end{array}$ & \begin{tabular}{|c|} 
of \\
effectiv \\
e t \\
$>10^{\circ} \mathrm{C}$
\end{tabular} & $\begin{array}{l}\sum \text { of } \\
\text { activ } \\
\text { e t }\end{array}$ & $\begin{array}{c}\text { Rainfall, } \\
\mathrm{mm}\end{array}$ & HTC & $\begin{array}{c}\text { Rainy days } \\
\text { quantity } \\
\text { during } \\
\text { preharvest }\end{array}$ & $\begin{array}{l}\text { Theoretic- } \\
\text { meaning y, } \\
\text { days }\end{array}$ & $\begin{array}{l}\text { Deviation } \\
\text { from } \\
\text { actual } \\
\mathrm{y},\end{array}$ \\
\hline$y$ & $x_{1}$ & $x_{2}$ & $x_{3}$ & $x_{4}$ & $x_{5}$ & & & \\
\hline $\begin{array}{l}27.03-27.06 \\
(93)\end{array}$ & 885 & 473 & 1035 & 69 & 0.7 & 3 & 93 & - \\
\hline $\begin{array}{l}06.04-07.07 \\
(92)\end{array}$ & 791 & 424 & 1060 & 189 & 1.8 & 1 & 96 & +4 \\
\hline $\begin{array}{l}29.03-30.06 \\
(94)\end{array}$ & 772 & 396 & 1083 & 269 & 2.5 & 1 & 99 & +5 \\
\hline $\begin{array}{l}15.03-22.06 \\
(98)\end{array}$ & 800 & 380 & 1132 & 124 & 1.1 & 2 & 92 & -6 \\
\hline $\begin{array}{l}17.03-22.06 \\
(97)\end{array}$ & 737 & 304 & 1035 & 296 & 2.9 & - & 98 & +1 \\
\hline $\begin{array}{l}22.03-11.07 \\
(112)\end{array}$ & 933 & 480 & 1209 & 285 & 2.4 & 5 & 103 & -9 \\
\hline $\begin{array}{l}25.03-07.07 \\
(105)\end{array}$ & 836 & 414 & 1025 & 306 & 3.0 & 3 & 100 & -5 \\
\hline $\begin{array}{l}17.03-29.06 \\
(103)\end{array}$ & 784 & 595 & 1089 & 220 & 2.0 & 1 & 98 & -5 \\
\hline $\begin{array}{l}25.03-27.06 \\
(95)\end{array}$ & 741 & 327 & 1122 & 140 & 1.3 & - & 91 & -4 \\
\hline $\begin{array}{l}03.04-06.07 \\
(94)\end{array}$ & 926 & 516 & 1304 & 225 & 1.7 & 1 & 98 & +4 \\
\hline $\begin{array}{l}04.04-02.07 \\
(89)\end{array}$ & 957 & 568 & 1294 & 156 & 1.2 & - & 92 & +3 \\
\hline $\begin{array}{l}01.04-03.07 \\
(94)\end{array}$ & 824 & 454 & 1092 & 236 & 2.2 & 2 & 98 & +4 \\
\hline $\begin{array}{l}01.04-03.07 \\
(91)\end{array}$ & 911 & 473 & 1172 & 171 & 1.5 & 2 & 94 & +3 \\
\hline $\begin{array}{l}27.03-30.06 \\
(96)\end{array}$ & 949 & 521 & 1286 & 128 & 1.0 & 1 & 89 & +7 \\
\hline $\begin{array}{l}01.04-27.06 \\
(88)\end{array}$ & 908 & 498 & 1232 & 167 & 1.4 & - & 92 & +4 \\
\hline Average (96) & 850 & 455 & 1145 & 199 & 1.8 & & 95.5 & \\
\hline $\mathrm{V}(6.6)$ & 9.1 & 18.1 & 8.6 & 35.6 & 39.0 & & 4.2 & \\
\hline
\end{tabular}

That is, depending on weather conditions, it may be stretched. But, mainly, the beginning of the black currant growth is fixed at the end of March - early April. The mass harvest of fruits occurs mainly in late June or early July.

Given the slight variation in the indicator (coefficient of $6.6 \%$ ), it can be assumed that the duration of the vegetation period for black currant is $96 \pm 3-4$ days. 
Within 6 days, decisions should be taken regarding the priority of fruits harvesting of different ripeness.

The minimum sum of effective and active temperatures necessary for the normal growth and fruiting of black currant in the zone of the Forest-Steppe is determined: the sum of effective temperatures is above $5^{\circ} \mathrm{C}-750-950^{\circ}$ (average $-850^{\circ}$ ), the sum of effective temperatures is above $10{ }^{\circ} \mathrm{C}-300-600^{\circ}$ (average $-455^{\circ}$ ), the sum of active temperatures is $1050-1300^{\circ}$ (average $-1145^{\circ}$ ). These indices are objective for determining the consumer degree of fecundity of the black currant fruit.

The amount of moisture content of black currant (rainfall) during the years of research varied considerably (coefficient of variation is $35.6 \%$ ) $-120-300 \mathrm{~mm}$ (average is $199 \mathrm{~mm}$ ), which corresponds to the unstable moisture zone. This is evidenced by HTC - from 0.7 (typical for the Steppe) to 3.0 (characteristic for excessive moisture). However, mainly HTC was fixed at the level of 1-2, which is characterized by conditions of sufficient moisture.

The amount of moisture content of black currant (rainfall) during the years of research varied considerably (coefficient of variation is $35.6 \%$ ) $-120-300 \mathrm{~mm}$ (average is $199 \mathrm{~mm}$ ), which corresponds to the unstable moisture zone. This is evidenced by HTC - from 0.7 (typical for the Steppe) to 3.0 (characteristic for excessive moisture). However, mainly HTC was fixed at the level of 1-2, which is characterized by conditions of sufficient moisture.

The correlation and regression analysis of the linear dependence between the duration of the vegetation period $(y)$ and the agroclimatic parameters are carried out: the sum of effective temperatures above $5^{\circ} \mathrm{C}\left(x_{1}\right)$, the sum of effective temperatures above $10^{\circ} \mathrm{C}\left(x_{2}\right)$, the sum of active temperatures $\left(x_{3}\right)$, rainfall $\left(x_{4}\right)$ and $\mathrm{HTC}\left(x_{5}\right)$. The correlation between the indicators of the duration of the vegetation period and the amounts of effective and active temperatures is weak, and precipitation and HTC is moderate and does not meet practical needs. At the same time, the impact of all indicators affects the meaning of a productive feature:

$$
r=0.618 \pm 0.022
$$

The equation has the following form:

$$
y=146+0.0194 x_{1}-0.00353 x_{2}-0.0664 x_{3}+0.359 x_{4}-34.06 x_{5}
$$

The deviation of the theoretical indicator from a practical one is usually $3-5$ days.

Depending on the agroclimatic parameters (see Table 2), the highest and high content of ascorbic acid in the fruits during the growing season was noted under conditions when:

- the sum of effective temperatures above $5{ }^{\circ} \mathrm{C}$ and $10{ }^{\circ} \mathrm{C}$ are close to medium, large and significantly larger meanings, and the sum of active temperatures are smaller and significantly less than average, rainfall slightly higher of average (HTC $-2.0,2.2$ ), or less than average (HTC -1.0 );

- the sum of effective temperatures above $5{ }^{\circ} \mathrm{C}$ and $10{ }^{\circ} \mathrm{C}$ and the active ones are higher and considerably higher than average, and rainfall is less (HTC - 1.2;1.4) or more (HTC - 1.2; 1.7) average;

- the sum of effective temperatures above $5^{\circ} \mathrm{C}$ and $10^{\circ} \mathrm{C}$ and the active ones are 
less than average and the sum of rainfall is less than average (HTC - 1.3).

Low content of ascorbic acid in black currant fruit is determined under conditions when:

- the sum of the effective temperatures above $5{ }^{\circ} \mathrm{C}$ and $10{ }^{\circ} \mathrm{C}$ and active ones are bigger and much higher than average, and the amount of rainfall is less than average (HTC - 1.0, 1.4; 1.5);

- the sum of the effective temperatures above $5{ }^{\circ} \mathrm{C}$ and $10{ }^{\circ} \mathrm{C}$ and the sum of active ones are close or lower than average, and the amount of rainfall is much higher than average (HTC - 3.0).

The analysis of the received data shows the ambiguous influence of the HTC indicator on the accumulation of ascorbic acid in black currant fruits.

Conclusion. Thus, the high C-vitality of black currant fruit depends to a large extent on the variety, and only then on weather conditions during the formation of the harvest. In the present work the impact of both genotype and environment on fruit ascorbic acid content is highlighted and it is shown that while prevailing environmental conditions can have a significant impact on the ascorbic acid content of fruit, underlying genetic factors also have a role with phenotypic hierarchy generally maintained year-to-year. These data suggest that breeding for ascorbic acid content in black currant is an achievable aim.

\section{Лiтература}

1. Osokina N., Kostetska K., Gerasymchuk H. Formation of Frozen Blackcurrant Fruits Quality. Annual Research \& Review in Biology. 2020. Vol. 35 (Issue 10). P. 97-112.

2. Підрушняк А., Голинко О., Чумак Н. Функціональні харчові продукти - поточний стан проблеми. Продукти \& Інгредієнти. 2004. №5 (6), C. 22-24.

3. Walker P. G., Gordon S. L., Brennan R. M., Hancock R. D. A highthrough-put monolithic HPLC method for the rapid vitamin $\mathrm{C}$ phenotyping of berry fruit. Phytochemical Analysis. 2006. Vol. 17. P. 284-290.

4. Badejo A. A., Tanaka N., Esaka M. Analysis of GDP-D-mannose pyrophosphorylase gene promoter from acerola (Malpighia glabra) and increase in ascorbate content of transgenic tobacco expressing the acerola gene. Plant and Cell Physiology. 2008. Vol. 49. P. 126-132.

5. Brennan R.M., Jorgensen L., Hackett C., Woodhead M., Gordon S., Russell J. The development of a genetic linkage map of blackcurrant (Ribes nigrum L.) and the identification of regions associated with key fruit quality and agronomic traits. Euphytica. 2008. Vol. 161. P. 19-34.

6. Buendía B., Allende A., Nicolás E., Alarcón JJ, Gil M.I. Effect of regulated deficit irrigation and crop load on the antioxidant compounds of pea-ches. Journal of Agricultural and Food Chemistry. 2008. Vol. 56. P. 3601-3608.

7. Bulley S. M., Rassam M., Hoser D., Otto W., Schünemann N., Wright M., MacRae E., Gleave A., Laing W. Gene expression studies in kiwifruit and gene over-expression in Arabidopsis indicates that GDP-L-galactose gua-nyltransferase is 
a major control point of vitamin C biosynthesis. Journal of Experimental Botany. 2009. Vol. 60. P. 765-768.

8. $\quad$ Finn R.D., Tate J., Mistry J., Coggill P.C., Sammut S.J., Hotz H-R., Ceric G., Forslund K., Eddy S.R., Sonnhammer E.L.L., Bateman A. The Pfam protein family database. Nucleic Acids Research Database issue. 2008. Vol. 36. P. 281-288.

9. Gawel R. Red wine astringency: a review. Australian Journal of Grape and Wine Research. 2008. № 4. P 74-95.

10. Li M-J., Ma F-W., Zhang M., Pu F. Distribution and metabolism of ascorbic acid in apple fruits (Malus domestica Borkh cv. Gala). Plant Science. 2008. Vol. 174. P. 606-612.

11. Linster C. L., Adler L. N., Webb K., Christensen K. C., Brenner C., Clarke S. G. A second GDP-L-galactose phosphorylase in Arabidopsis en route to vitamin C. Covalent intermediate and substrate requirements for the con-served reaction. The Journal of Biological Chemistry. 2008. Vol. 283. P. 18483-18492.

12. Linster C.L., Clarke S.G. L-Ascorbate biosynthesis in higher plants: the role of VTC2. Trends in Plant Science. 2008. Vol. 13. P. 567-573.

13. Müller-Moulé P. Plant. Molecular Biology. 2008. № 68. P. 31-41.

14. Чирков Ю. Агрометеорология. Л.: Гидрометеоиздат, 1986. 293 с.

15. Плешков Б. П. Практические занятия по биохимии. М.: Колос, 1976. $254 \mathrm{c}$.

16. ДСТУ 8319:2015. Смородина чорна свіжа. Технічні умови. Київ: Державний Стандарт України, 2017, 8 с.

17. Боровиков В. П., Боровиков И. П. Statistica. Статистический анализ и обработка данных в среде Windows [Текст]. М.: Филинъ, 1997. 608 с.

18. Царенко О. М., Злобін Ю. А., Скляр В. Г. Комп'ютерні методи в сільському господарстві та біології: Навчальний посібник. Суми: Університетська книга, 2000. 203 с.

\section{References}

1. Osokina, N., Kostetska, K., Gerasymchuk, H. (2020). Formation of Frozen Blackcurrant Fruits Quality. Annual Research \& Review in Biology, no. 35 (10), pp. 97-112.

2. Podrushniak, A., Golynko, O., Chumak, N. (2004). Functional food products are the current state of the issue. Products \& Ingredients, no. 5 (6), pp. 22 24. (in Ukrainian).

3. Walker, P.G., Gordon, S.L., Brennan, R.M., Hancock, R.D. (2006). A high-through-put monolithic HPLC method for the rapid vitamin C phenotyping of berry fruit. Phytochemical Analysis, no. 17, pp. 284-290.

4. Badejo, A.A., Tanaka, N., Esaka, M. (2008). Analysis of GDP-Dmannose pyro-phosphorylase gene promoter from acerola (Malpighia glabra) and increase in ascorbate content of transgenic tobacco expressing the acerola gene. Plant and Cell Physiology, no. 49, pp. 126-132.

5. Brennan, R.M., Jorgensen, L., Hackett, C., Woodhead, M., Gordon, S., Russell, J. (2008). The development of a genetic linkage map of blackcurrant (Ribes 
nigrum L.) and the identification of regions associated with key fruit quality and agronomic traits. Euphytica, no. 161, pp. 19-34.

6. Buendía, B., Allende, A., Nicolás, E., Alarcón, JJ, Gil, M.I. (2008). Effect of regu-lated deficit irrigation and crop load on the antioxidant compounds of pea-ches. Journal of Agricultural and Food Chemistry, no. 56, pp. 3601-3608.

7. Bulley, S. M., Rassam, M., Hoser, D., Otto, W., Schünemann, N., Wright, M., MacRae, E., Gleave, A., Laing, W. (2009). Gene expression studies in kiwifruit and gene over-expression in Arabidopsis indicates that GDP-L-galactose gua-nyltransferase is a major control point of vitamin $\mathrm{C}$ biosynthesis. Journal of Experimental Botany, no. 60, pp. 765-768.

8. $\quad$ Finn, R. D., Tate, J., Mistry, J., Coggill, P.C., Sammut, S. J., Hotz, H-R., Ceric, G., Forslund, K., Eddy, S. R., Sonnhammer, E.L.L., Bateman, A. (2008). The Pfam protein family database. Nucleic Acids Research Database issue, no. 36, pp. 281-288.

9. Gawel, R. (2008). Red wine astringency: a review. Australian Journal of Grape and Wine Research, no. 4, pp. 74-95.

10. Li, M-J., Ma, F-W., Zhang, M., Pu, F. (2008). Distribution and metabolism of ascorbic acid in apple fruits (Malus domestica Borkh cv. Gala). Plant Science, no. 174, pp. 606-612.

11. Linster, C. L., Adler, L. N., Webb, K., Christensen, K. C., Brenner, C., Clarke, S.G. (2008). A second GDP-L-galactose phosphorylase in Arabidopsis en route to vitamin $\mathrm{C}$. Covalent intermediate and substrate requirements for the conserved reaction. The Journal of Biological Chemistry, no. 283, pp. 18483-18492.

12. Linster, C. L., Clarke, S.G. (2008). L-Ascorbate biosynthesis in higher plants: the role of VTC2. Trends in Plant Science, no. 13, pp. 567-573.

13. Müller-Moulé, P. (2008). Plant. Molecular Biology, 68, pp. 31-41.

14. Chirkov, Yu. (1986). Agrometeorology. Leningrad: Hydrometeoizdat. 293 p. (in Russian).

15. Pleshkov, B. P. (1976). Practical Training on Biochemistry. M.: Kolos. 254 p. (in Russian).

16. SSU 8319:2015. (2017). Black currants are fresh. Specifications. Kyiv: State standard Ukraine. 8 p. (in Ukrainian).

17. Borovikov, V. P., Borovikov, I. P. (1997). Statistics. Statistical analysis and data processing in the Window. M.: Filin. 608 p. (in Russian).

18. Tsarenko, O. M., Zlobin, Yu. A., Skliar, V. G., Panchenko, S. M. (2000). Computer methods in agriculture and biology: study guide. Sumy: Universytetska knyga. 203 p. (in Ukrainian).

\section{Аннотация}

\section{Осокина Н., Костецкая Е., Герасимчук Е.} Аскорбиновая кислота в плодах черной смородины

Приведенные результаты 15-летних исследований по содержанию аскорбиновой кислоты в плодах черной смородины. Во время вегетации черной смородины было подсчитано: сумму эффективных температур выше $5{ }^{\circ} \mathrm{C}$; сумму эффективных температур выше $10{ }^{\circ} \mathrm{C}$; величину активных температур; количество осадков; гидротермический коэффициент (ГТК). В ходе исследования изучали продолжительность роста черной смородины и агроклиматические показатели в этот период; содержание аскорбиновой 
кислоты в плодах черной смородины в зависимости от сорта и года сбора урожая.

Целью исследования было проанализировать содержание аскорбиновой кислоты в плодах черной смородины пяти сортов в течение многих лет исследований.

Установлено, что продолжительность сезона выращчивания черной смородины в условиях Правобережной Лесостепи Украины составляет $96 \pm 3-$ 4 дня. Причем сумма эффективных температур выше $5{ }^{\circ} \mathrm{C}$ составляла 750$950^{\circ}$, сумма эффрективных температур выне $10{ }^{\circ} \mathrm{C}-300-600^{\circ}$, сумма активных температур - 1050-1300, осадков - 120-300 мм, ГТК - 0,7-3,0.

В статье приведень закономерности синтеза аскорбиновой кислоть в зависимости от особенностей сорта и агроклиматических показателей во время вегетации растений. Анализ полученных данных показывает неоднозначное влияние показателя НТС на накопление аскорбиновой кислоть в плодах черной смородины.

Всестороннее и всестороннее изучение самых сложных деталей метаболизма веществ показало, что аскорбиновая кислота играет одну из ответственных ролей в процессе всего цчикла внутриутробного развития растений от появления до исчезновения - роль непосредственного участника процесса дыхание, фотосинтез, регуляция активности ферментов $u$ коферментов, общий обмен и транспорт веществ, защзита клеток от окислительного стресса, вызванного абиотическими факторами.

Таким образом, высокое содержание витамина $C$ плодами черной смородины в значительной степени зависит от их сорта, а только потом от погодных условий при формировании урожая.

Ключевые слова: черная смородина, сорт, качество, химический состав, аскорбиновая кислота.

\section{Annotation}

\section{Osokina N., Kostetska K., Gerasymchuk $\mathrm{H}$. Ascorbic acid in black currant fruits}

The ascorbic acid content of five varieties of black currants during 15 years of research is given. During the growing season of black currant it was counted: the sum of effective temperatures above $5^{\circ} \mathrm{C}$; the sum of effective temperatures above 10 ${ }^{\circ} \mathrm{C}$; amounts of active temperatures; amount of rainfall; hydrothermal coefficient (HTC).

The research objective was to analyze ascorbic acid content in black currant fruit during many years of research. Research tasks were meant to establish black currant growth duration and agroclimatic indicators during this period; ascorbic acid content in black currant fruits depending on the variety and the year of the harvest.

It is established that the duration of the black currant growing season in the conditions of the Right-Bank Forest-Steppe ofUkraineis $96 \pm 3-4$ days for thermal resources:the sum of effective temperatures is above $5^{\circ} \mathrm{C}-750-950^{\circ}$, the sum of effective temperatures is above $10^{\circ} \mathrm{C}-300-600^{\circ}$, the sum ofative temperatures is $1050-1300^{\circ}$ and the rainfall is 120-300 mm, for the HTC it is 0,7-3,0. The regularities of ascorbic acid synthesis are shown depending on the features of the variety and agroclimatic indices during vegetation of plants. The analysis of the 
received data shows the ambiguous influence of the HTC indicator on the accumulation of ascorbic acid in black currant fruits. A comprehensive and comprehensive study of the most complex details of the metabolism of substances showed that ascorbic acid plays one of the crucial roles in the entire cycle of intrauterine development of plants from emergence to disappearance - the role of a direct participant in the process of respiration, photosynthesis, regulation of the activity of enzymes and coenzymes, general metabolism and transport of substances, protecting cells from oxidative stress caused by abiotic factors.

Thus, the high $C$-vitality of black currant fruit depends to a large extent on the variety, and only then on weather conditions during the formation of the harvest.

Key words: black currant, variety, quality, chemical composition, ascorbic acid

УДК 633.361; 631.8

DOI 10.31395/2415-8240-2020-97-1-91-102

\title{
ECONOMIC AND ENERGY EVALUATION OF THE ELEMENTS OF GROWING TECHNOLOGY OF DIFFERENT SPECIES OF SAINFOIN IN THE RIGHT-BANK FOREST-STEPPE
}

\author{
H. I. Demydas, Doctor of Agricultural Sciences, Professor \\ E. S. Lykhosherst, post-graduate student \\ The National University of Life and Environmental Sciences of Ukraine \\ N. M. Poltoretska, Candidate of Agricultural Sciences \\ Uman National University of Horticulture
}

Наведено результати досліджень, щзодо економічної та біоенергетичної оцінки вирощування різних видів еспарцету залежно від удобрення, висоти скошування травостою, інокулячї насіння та років використання. Встановлено, що найвищий умовно чистий прибуток та найнижчу собівартість кормової одиниці та сирого протеїну мали за виромування еспариету посівного, економічні показники вирощування еспариету закавказького та піщаного видів значно поступалися першому. Найвищий коефіцієнт енергетичної ефективності та найменші затрати енергії на виромування 1 тонни кормових одиниць отримали на посівах еспариету посівного сорту Аметист Донецьький.

Ключові слова: еспариет посівний, закавказький, піщаний, удобрення, висота скошування, економіка, біоенергетична оцінка.

Analysis of recent researches and publications. The highest condition for the accelerated development of livestock production in the country is the creation of a strong fodder base. This directly affects the ability to increase livestock amount and its productivity. The reform of agriculture led to a sharp reduction in sown areas under perennial legumes, which in turn affected the flow of organic matter into the soil. Insufficient application of organic and mineral fertilizers significantly worsens of soil fertility, which negatively affects the level of agricultural crops productivity. 